\title{
Distinguishing between different beef production systems using $\alpha$-tocopherol, $\beta$-carotene and lutein measurements in beef
}

F.T. Roehrle ${ }^{1}$, A.P. Moloney ${ }^{2}$, O. Schmidt ${ }^{1}$, S.M. Harrison ${ }^{1}$, F.J. Monahan ${ }^{1}$

${ }^{1}$ School of Agriculture, Food Science and Veterinary Medicine, University College Dublin, Dublin, Ireland

${ }^{2}$ Teagasc, Grange Beef Research Centre, Dunsany, Co. Meath, Ireland

Email:frank.monahan@ucd.ie

Introduction Food authentication is an issue of increasing interest to consumers and food producers alike amid concerns about the origin of food and, in the case of animal-derived foods such as meat, concerns about its mode of production. Grass-based beef production is of particular interest to consumers because of its perceived healthiness and natural, animalfriendly production. The aim of the research was to determine if $\alpha$-tocopherol, $\beta$-carotene and lutein measurements in beef could be used to distinguish between different beef production systems.

Material and methods Charolais $\times$ Limousin crossbred heifers were assigned to one of four treatments (25 heifers per treatment): grazed pasture from November 2006 to October 2007 (P); pasture silage offered ad libitum indoors from November 2006 to April 2007, then grazed pasture from April to October 2007 (SiP); pasture silage offered ad libitum indoors from November 2006 to April 2007, then grazed pasture plus 0.5 of the diet dry matter (DM) as supplementary concentrates from April to October 2007 (SiPC); concentrates and straw indoors from November 2006 to October 2007 (C). Mean ( \pm s.d.) initial live weight was $275 \pm 27.0 \mathrm{~kg}$ and the mean initial age was $252 \pm 28$ days. The composition of the concentrate was $430 \mathrm{~g} \mathrm{~kg}^{-1}$ rolled barley, $430 \mathrm{~g} \mathrm{~kg}^{-1}$ molassed beet pulp, $80 \mathrm{~g} \mathrm{~kg}^{-1}$ soybean meal, $35 \mathrm{~g} \mathrm{~kg}^{-1} \mathrm{molasses} 20 \mathrm{~g}$ $\mathrm{kg}^{-1}$ mineral/vitamin premix and $5 \mathrm{~g} \mathrm{~kg}^{-1}$ lime. The concentrate allowance for the $\mathrm{C}$ group was adjusted periodically to maintain a similar rate of growth to that the P group. At the end of the experiment the mean ( \pm s.d.) carcass weight was 275 $\pm 21.6 \mathrm{~kg}$. Muscle (longissimus dorsi) and subcutaneous adipose tissue samples were taken for analysis following postmortem storage of carcasses for $48 \mathrm{~h}$ at $4^{\circ} \mathrm{C}$. Muscle $\alpha$-tocopherol was extracted using a modified method of Buttriss and Diplock (1984) and determined by HPLC using an Agilent 1200 series (Agilent Technologies Inc.) equipped with a variable loop injector and a Synergi Hydro - RP 80A $(250 \mathrm{~mm} \times 4.6 \mathrm{~mm}), 4 \mu \mathrm{m}$ particle size column. The mobile phase was methanol-water $(99: 1, \mathrm{v} / \mathrm{v})$ at a flow rate of $2 \mathrm{ml} \mathrm{min}^{-1}$ with detection by a diode array detector (Agilent Technologies, 1200 series) set at $292 \mathrm{~nm}$. $\beta$-Carotene and lutein in adipose tissue were extracted following the method of Strachan et al. (1993) and determined by HPLC with a Phenomenex Jupiter C18 analytical column 300A $(250 \mathrm{~mm} \times 4.6 \mathrm{~mm}), 5 \mu \mathrm{m}$ particle size column. $\beta$-Carotene and lutein were eluted isocratically with methanol-water (99:1, v/v) at a flow rate of $2 \mathrm{ml}$ $\min ^{-1}$, and detected at $436 \mathrm{~nm}$ and $450 \mathrm{~nm}$, respectively. Statistical analysis of the data was performed using the SPSS software package. Analysis of variance (ANOVA) followed by a post hoc Newman - Keuls multiple comparison test was used to determine if significant differences existed between the P, SiP, SiPC and C groups. Principal component analysis (PCA) was performed and used as a pattern recognition method.

Results Mean ( \pm s.d.) $\alpha$-tocopherol concentrations of muscle from the P $\left(2.63 \pm 0.58 \mu \mathrm{g} \mathrm{g}^{-1}\right)$ and $\mathrm{SiP}(2.43$ $\left.\pm 0.86 \mu \mathrm{g} \mathrm{g}^{-1}\right)$ groups were higher $(\mathrm{P}<0.05)$ than those of the SiPC group $\left(1.77 \pm 0.54 \mu \mathrm{g} \mathrm{g}^{-1}\right)$ which, in turn, was higher $(\mathrm{P}<0.05)$ than that of the $\mathrm{C}$ group $(1.14 \pm$ $\left.0.40 \mu \mathrm{g} \mathrm{g}^{-1}\right)$. The lutein concentration in adipose tissue differed significantly between groups $(\mathrm{P}<0.05)$ with values (mean \pm s.d.) of $0.13 \pm 0.02 \mu \mathrm{g} \mathrm{g}^{-1}, 0.10 \pm$ $0.03 \mu \mathrm{g} \mathrm{g}^{-1}, 0.08 \pm 0.03 \mu \mathrm{g} \mathrm{g}^{-1}$ and $0.04 \pm 0.01 \mu \mathrm{g} \mathrm{g}^{-1}$ for the P, SiP, SiPC and C groups, respectively. Mean ( \pm s.d.) $\beta$-carotene concentrations of adipose tissue from the $\mathrm{P}\left(0.54 \pm 0.15 \mu \mathrm{g} \mathrm{g}^{-1}\right), \operatorname{SiP}\left(0.49 \pm 0.11 \mu \mathrm{g} \mathrm{g}^{-}\right.$ $\left.{ }^{1}\right)$ and $\operatorname{SiPC}\left(0.49 \pm 0.11 \mu \mathrm{g} \mathrm{g}^{-1}\right)$ groups were significantly higher $(\mathrm{P}<0.05)$ than those of $\mathrm{C}$ group $\left(0.09 \pm 0.04 \mu \mathrm{g} \mathrm{g}^{-1}\right)$. The PCA plot (Figure 1) revealed that it is possible to distinguish between beef from the $\mathrm{C}$ group and the other groups.

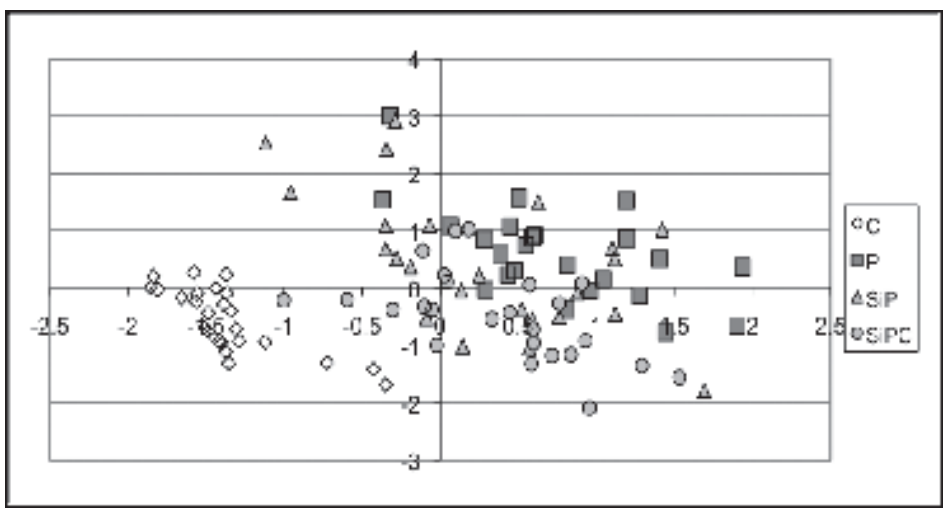

Figure 1 PCA score plot of principal component 2 versus principal component 1 for all samples following $\alpha$-tocopherol, $\beta$-carotene and lutein analysis.

Conclusions Following analysis of $\alpha$-tocopherol, $\beta$-carotene and lutein in beef it is possible to distinguish beef from animals fed a diet based on concentrates and diets containing pasture or pasture/pasture silage/concentrate combinations but not between beef from animals fed the various pasture/pasture silage/concentrate combinations.

Acknowledgements The authors gratefully acknowledge funding from the Irish Department of Agriculture, Fisheries and Food under the Food Institutional Research Measure.

\section{References}

Buttriss, J.L. and Diplock, A.T. 1984. Methods in Enzymology 105, 131-138.

Strachan, D.B., Yang, A. and Dillon, R.D. 1993. Australian Journal of Experimental Agriculture 33, 269-273 